\title{
Comparative experience of socio-pedagogical work with gifted children in the Russian Federation and Kazakhstan
}

\section{Experiencia comparada del trabajo sociopedagógico con niños superdotados en la Federación de Rusia y Kazajstán}

\author{
O.S. Shcherbinina \\ Candidate of Pedagogical Sciences, Associate Professor, Associate Professor of Psychological \\ and Pedagogical Education Department, FSBEI HPE “Kostroma State University”, Russian \\ Federation. \\ ORCID: http://orcid.org/0000-0001-8203-0489

\section{D.V.Lepeshev} \\ Candidate of Pedagogical Sciences, Professor, Academician of the Academy of Pedagogical \\ Sciences of Kazakhstan, Deputy Vice-Rector for Research and International Cooperation of \\ Kokshetau University named after A. Myrzakhmetov, Kazakhstan. \\ ORCID: https://orcid.org/0000-0002-9256-1571
}

\section{I.N. Grushetskaya}

Candidate of Pedagogical Sciences, Associate Professor, Associate Professor of Psychological and Pedagogical Education Department, FSBEI HPE "Kostroma State University”, Russian

Federation.

ORCID: http://orcid.org/0000-0001-8361-7513

\section{Zh. A. Zakharova}

Doctor of Pedagogical Sciences, Professor, Head of the Department of Psychological and Pedagogical Education, FSBEI HPE “Kostroma State University”, Russian Federation.

ORCID: http://orcid.org/0000-0003-4761-6200

\section{A.V.Afanasov}

Candidate of Pedagogical Sciences, Associate Professor, Associate Professor of the Department of Social Pedagogy and Organization of Work with Youth, FSBEI HPE "Yaroslavl State Pedagogical University named after K.D. Ushinsky", Russian Federation. ORCID: https://orcid.org/0000-0003-0614-1085

Received 09-08-20 Revised 10-10-20

*Correspondence

Email: Shcherbinina@gmail.com

\section{Accepted 20-12-21 On line 01-29-21}

Cite as:
Shcherbinina, O.S., Lepeshev, D.V., Grushetskaya, I.N., Zakharova, Zh. A., Afanasov, A.V. (2021). A Comparative experience of socio-pedagogical work with gifted children in the Russian Federation and Kazakhstan. Propósitos y Representaciones, 9 (SPE1), e963. Doi: http://dx.doi.org.10.20511.pyr2021.v9nSPE2.963 


\section{Summary}

The authors conduct a comparative analysis of the features and content of sociopedagogical work with gifted schoolchildren in the educational space of Russia and Kazakhstan. The purpose of our study: to study and present the comparative experience of socio-pedagogical work with gifted children in the Russian Federation and Kazakhstan. Collection of empirical data was carried out by questionnaire survey of teachers of general educational organizations of the Russian Federation $(n=225)$ and educational organizations of Kazakhstan $(n=200)$. The survey of teachers and specialists of educational organizations was conducted in 2018 and 2019.The authors have studied the comparative experience of organizing socio-pedagogical work with gifted schoolchildren in Russia and Kazakhstan. The results allow us to see common and specific in the work with gifted children in the Russian Federation and the former postSoviet republic. The identified features can be taken into account in the organization of socio-pedagogical work with gifted schoolchildren and improve the effectiveness of socio-pedagogical work and socio-pedagogical support of gifted schoolchildren. In conclusion, the study of comparative experience of socio-pedagogical work with gifted schoolchildren in two countries with a similar history of formation of educational systems allows us to see the difference in approaches to work with this non-standard category of children at the moment. The identified specificity in the programs, forms and methods, target benchmarks of socio-pedagogical work with gifted children in educational organizations can be taken into account when developing the content of this direction of work and will improve its effectiveness.

Keywords: Gifted child, Socialization, Socio-pedagogical work, General educational organizations, Russia, Kazakhstan.

\section{Resumen}

Los autores realizan un análisis comparativo de las características y el contenido del trabajo sociopedagógico con escolares superdotados en el espacio educativo de Rusia y Kazajstán. El propósito de nuestro estudio: estudiar y presentar la experiencia comparativa del trabajo sociopedagógico con niños superdotados en la Federación de Rusia y Kazajstán. La recopilación de datos empíricos se llevó a cabo mediante una encuesta de cuestionario a profesores de organizaciones educativas generales de la Federación de Rusia $(n=225)$ y organizaciones educativas de Kazajstán $(n=200)$. La encuesta de maestros y especialistas de organizaciones educativas se realizó en 2018 y 2019.Los autores han estudiado la experiencia comparada de organizar el trabajo sociopedagógico con escolares superdotados en Rusia y Kazajstán. Los resultados nos permiten ver algo común y específico en el trabajo con niños superdotados en la Federación de Rusia y la ex república postsoviética. Las características identificadas pueden tenerse en cuenta en la organización del trabajo sociopedagógico con escolares superdotados y mejorar la eficacia del trabajo sociopedagógico y el apoyo sociopedagógico de los escolares superdotados. En conclusión, el estudio de la experiencia comparativa del trabajo sociopedagógico con escolares superdotados en dos países con una historia similar de formación de sistemas educativos nos permite ver la diferencia en los enfoques para trabajar con esta categoría no estándar de niños en este momento. La especificidad identificada en los programas, formas y métodos, puntos de referencia objetivo del trabajo sociopedagógico con niños superdotados en organizaciones educativas se puede tener en cuenta al desarrollar el contenido de esta dirección de trabajo y mejorará su efectividad.

Palabras clave: Niño superdotado, Socialización, Trabajo sociopedagógico, Organizaciones educativas generales, Rusia, Kazajstán. 


\section{Introduction}

Formation of the education system in the former USSR took place simultaneously on the whole territory of the vast country. With the acquisition of sovereignty by the union republics, the development of education system in each of them has acquired its own line of development.

The majority of the Union republics, including Kazakhstan, in the basis of their work left the Soviet system and modified it on the basis of national, religious and resource opportunities. During the twenty-eight years of the post-Soviet period, each republic has accumulated its own unique experience of educational activity, including work with special categories of children.

For example, the legislation of Kazakhstan uses the term "elite education" as the knowledge gained through different curricula implemented by specialized educational organizations for gifted people in Kazakhstan.

The emphasis in education in Kazakhstan is on the $4 \mathrm{~K}$ model: developing creativity, critical thinking, communication and teamwork skills.

The republic has a significant experience of giftedness. Talented children are the national intellectual potential. The "Daryn" Republican Scientific and Technical Center has been working in the republic for several years. It is through this national organization that children of Kazakhstan have the opportunity to demonstrate their knowledge and represent the country at international competitions (5).

The work with gifted children at the present stage of development of the educational system in Russia is built mainly in three directions: work in general educational organizations, work in the system of additional education and academic competitions movement. The most developed from the point of view of content and methodology is the area of work with gifted schoolchildren. Special importance for modern teachers working with gifted children has the Working concept of giftedness, developed by a team of Russian scientists under the leadership of D.B. Bogoyavlenskaya (1).

Specialized centers for working with gifted children have been successfully working in Russia in recent years, which not only provide opportunities for their development, but also become a place that accumulates modern best practices with this category of students.

One of the leading institutions of additional education working with gifted children is the "Sirius" All-Russian educational center for gifted children (Sochi), which was created at the initiative of Vladimir Putin - President of the Russian Federation and opened on June 01, 2015. It was established to help develop the talents and abilities of children. First of all, in those areas in which Russia leads the world - in the exact sciences (mathematics, physics, chemistry, biology), art (classical ballet, painting, academic music) and sports (hockey, figure skating, chess).

Both Russia and Kazakhstan have their own unique experience of working with gifted children, which can be compared in order to identify the strengths of the development of educational systems, the conditions of its effectiveness and their further application in the work with gifted children in Russia and Kazakhstan.

Theoretical and methodological aspects of the study and development of children's giftedness are presented in the works of D.B. Bogoyavlenskaya, N.S. Leytes, A.M. Matyushkin, J. Renzulli, A.I. Savenkov, P. Torrens, M.A.Kholodnaya, V.D. Shadrikov, N.B. Shumakova, V.S. Yurkevich, etc.

The main technologies and methods of teaching and development of gifted children are disclosed in the works of N.I.Avdeeva, E.A. Aksenova, Ye.S. Belova, M.A. Birzheva, I.P. Gladilina, T.N.Dzhumagulova, A.V. Zolotareva, Ye.P. Ilyin, A.I. Karmanchikov, 
M.A.Kolovanova, S.V. Kuznetsova, L.I. Larionova, N.S. Leytes, A.M.Matyushkin, A.I. Savenkov, V.E. Chudnovsky, N.B. Shumakova, V.S. Yurkevich, etc. (1; 4).

Development of models and projects of training teachers to work with gifted children was studied by M.A. Arsenova, M. Lindsley, A.M. Matyushkin, Ye.L.Melnikova, D.S. Molokov, T.G. Moroz, N.A. Pronina, T.V. Razumovskaya, T.G. Rakhmatullin, T.F. Sergeeva, Ye.V. Sechkareva, G.V. Tarassova, N.B.Shumakova, etc.

The following researches contributed to the solution of problems of gifted children in the Republic of Kazakhstan: theoretical and methodological bases of work with gifted children at the state and managerial level in the Republic of Kazakhstan (U.B. Zheksenbaeva); development of intellectual potential of gifted students (A.K. Kazieva, I.B. Otitskaya etc.); student reanimation in specialized schools of gifted (N.I. Darkhanov etc.); development of preschool children (O.A. Zhumadillaeva etc.), elementary school age (S. Kuznetsov, N.N.Telepneva etc.), creative talents; personal approach to teaching and development of gifted children (U.K.Satova etc.); scientific and practical basis for training the next teacher to work with gifted children (L. Mikikbaeva). Leading psychologists and teachers of the Daryn Republican ScientificPractical Center (E.M. Aryn, A.K. Akmetov, B.K. Damitov, U.B. Zheksenbaeva, N.D. Ivanova, N.K. Kasymov, Z.A. Karaev, S.N. Laktionova, N.I. Nurakhmetov) in the Republic, where modern trends in world science and practical experience in working with gifted children are generalized.

In many respects the work experience and research results of Russia and Kazakhstan are focused on the development of abilities of gifted children and organization of work with them at different age stages and different levels of education.

At that, researches of Russian scientists (L.A. Leutina, V.I. Panov, S.A.Khazova, V.S. Yurkevich, etc.) testify to the necessity to create conditions in the educational environment of school for socialization of a student's personality, subjectivity in search of knowledge, development of his social and communicative competence. Active work not only to develop the abilities of gifted children, but also to create conditions for social development of gifted children, development of their existential sphere is of particular importance nowadays $(6 ; 8 ; 10 ; 11 ; 12)$.

It is confirmed by foreign researches. Thus, the social component of life of gifted children and teenagers has been in the focus of close attention of foreign psychologists for several decades $(7 ; 9)$. The results of research by J.L. Davis, S.A.Robinson confirm the susceptibility of gifted children to bullying and speak about the necessity of special work with their psycho-emotional sphere, which requires high competence of specialists in this area (13). The works of A. Guez, H.Peyre, M. Le Cam, N. Gauvrit, F. Ramus (14) show the exposure of gifted children to the risk of failure at school in comparison with their peers.

In this regard, the organization of socio-pedagogical work with gifted children in modern educational organizations is of particular importance. Emphasis on this direction of activity with gifted children requires revision of priorities in the content of work with this non-standard category.

Acquaintance with experience of other countries developing independently, but having a similar educational system by structure, can help to solve this problem. In this case, the Union republics and, in particular, Kazakhstan have very interesting data.

This circumstance allows us to conduct a comparative analysis of the experience of socio-pedagogical work with gifted schoolchildren in Russia and Kazakhstan and try to identify conditions for effective work with gifted schoolchildren in this direction.

The aim of the article is to conduct a comparative analysis of the experience of sociopedagogical work with gifted schoolchildren in the Russian Federation and Kazakhstan. 


\section{Methodology}

The empirical study consisted of a survey of teachers from educational organizations of the Russian Federation: Kostroma, Yaroslavl, Galich $(n=132)$, teachers of supplementary education organizations in Kostroma, Yaroslavl, Kursk $(n=66)$ and teachers and specialists from the "Sirius" center in Sochi ( $\mathrm{n}=27)$; educational organizations in Kazakhstan: Kokshetau, Schuchinsk, Atbasar, Nur-Sultan, Karaganda, and others. $(n=200)$.

The survey of teachers and specialists of educational organizations was conducted in 2018 and 2019.

\section{Results}

The problem of working with gifted children in Russia is supported at the federal level through the implementation of specialized programs and in the content of legislative acts of the Russian Federation. This and the Law "On Education in the Russian Federation" and the Resolution of the Government of the Russian Federation "On the Federal Target Program of Education Development for 2016-2020" and others.

A significant boost in the development of work with gifted children in the Russian Federation was given by the implementation of the "Gifted Children" federal program, the goal of which was as follows:

1.Creation of favorable conditions for the development of talented students through an optimal structure of school and additional education.

2.Formation of a system of socio-psychological support for gifted and capable children. A network of specialized educational institutions oriented to work with gifted children at the federal, regional and municipal level of education system is currently developing in our country.

All new centers for the development of gifted children and youth open annually in our country. A striking example of such a center is the "Sirius" All-Russian educational center for gifted children, which was established at the initiative of Vladimir Putin President of the Russian Federation and opened on June 01, 2015.

According to the concept of the project, the "Sirius" center (Sochi) was established to promote the development of talents and abilities of children. Primarily:

- $\quad$ in exact sciences (mathematics, physics, chemistry, biology);

- $\quad$ Art (classical ballet, painting, academic music);

- $\quad$ Sports (hockey, figure skating, chess).

Gifted students participate in professional and general education programs, as well as in master classes and the work of creative and scientific laboratories under the guidance of leading scientists and expert practitioners.

The Center helps reach the maximum number of gifted children from all regions of the Russian Federation regardless of their families' social and financial status, as well as create a system of "social elevators".

Every month, 800 children aged 10-17 from dozens of Russian regions come to Sirius. They are accompanied by more than 100 teachers and coaches who improve their qualifications at the Center. Education is provided by the leading teachers of sports, physics and mathematics, chemistry and biology schools, as well as outstanding artists of Russian art in the field of academic music, classical ballet and fine arts. The educational program is designed for 24 days and includes classes in the specialty, as well as developing recreation, master classes, creative meetings with acknowledged professionals in their fields, a complex of recreational procedures, and during the school year, general education classes. 
The main objectives of the educational center for gifted children include the following: reaching the maximum number of gifted Russian schoolchildren and their teachers, promoting professional training in the Center's priority areas in all constituent entities of the Russian Federation;

- development of conditions for realization of intellectual and personal potential, professional self-determination and formation of children regardless of their place of residence, social status and financial possibilities of their families;

- development of new forms of inclusion of gifted children in intellectual and cognitive, artistic, sports and socially useful activities, using the potential of Sochi's Olympic infrastructure and the Center's partners;

- $\quad$ creating a system of "social elevators" for talented young Russians, combining career guidance, educational, sports, creative, research and other resources for the development and professional formation of children;

- $\quad$ forming incentives for partnership of different stakeholders, involvement of new participants, educators, experts, partners;

- $\quad$ efficiency in interaction with other children and mentors. Special attention will be paid to: the formation of leadership skills, the ability to manage their own projects and professional growth, the development of mathematical and creative thinking, cultural self-expression, skills to preserve and maintain health.

The conditions for self-realization of gifted children in the "Sirius" educational center are:

- $\quad$ organization of meaningful leisure activities for children;

- $\quad$ preserving and strengthening children's health;

- $\quad$ creating the necessary conditions for personal, creative, spiritual and moral development of children, for children to engage in physical education and sports, the development of creative abilities of children, the formation and development of positive motivation for a healthy lifestyle, law-abiding behavior in society;

- $\quad$ organizing accommodation for the children, providing them with nutritious meals and sufficient drinking water;

- $\quad$ educating and adapting children to life in society, inculcating self-management skills, a sense of collectivism and patriotism;

- $\quad$ fostering universal culture and values in children.

"Sirius" Educational Center combines the experience of the best Russian schools in order to create a national methodological and training center that develops replicable professional programs. These programs can be further used by teachers from the subjects of the Russian Federation who have received advanced training at the Center.

The Center monitors the progress and achievements of its gifted graduates, further employment in leading Russian artistic groups, cultural centers, national sports clubs, high-tech companies and scientific centers.

Indicators of the effectiveness of work with gifted children are an increase in the number of participants in the All-Russian Academic competition for schoolchildren, "Russian Bear" All-Russian linguistic game contest, "British Bulldog" English game contest, the All-Russian contest "CCT - computers, computer science, technology", "Olympus" All-Russian subject Academic competition for students in grades 1-9, "Intellectuals of the 21st century" All-Russian open conference of students and others.

It is important to note that modern educational organizations in Russia are largely subordinated in their activities to the implementation of federal educational standards and, in this regard, they value good academic performance, compliance with norms and rules of conduct. Children who "fall out" of the "framework of the average student" 
cause difficulties in their work, the need to organize additional psychological and pedagogical support. This also applies to gifted children, who, because of their dissimilarity, complexity, begin to experience pressure in the process of learning at school, both from teachers and from their peers.

The conducted studies indicate the need for special attention to the age-specific tasks of development and socialization of gifted schoolchildren. It shall not be only about the development of abilities of this category of children and their formal success, which is one side of the coin. It is important for the teacher to try not to lose sight of the complexities of a gifted child in the relationship with micro-society, in the formation of self-awareness and adequate self-esteem, in the formation of communication skills. It is important to understand that realization of creative and intellectual potential of a gifted child is possible to the full extent in case of successful solution of natural-cultural, sociocultural and socio-psychological tasks of socialization in the process of life activity (2).

We have been studying the success of solving age-related socialization problems of gifted children on the basis of educational organizations of Kostroma city for a number of years. During the work we used the following diagnostic tools:

- $\quad$ observation of gifted children;

- $\quad$ questionnaire survey of gifted children and teachers working with them; sociometry;

- $\quad$ The technique "Communicative and Organizational Abilities";

- $\quad$ Assessment technique of relations of the teenager with the class;

- $\quad$ M. Rokich Value Orientation Questionnaire, etc.

The studites revealed a number of difficulties in socialization of gifted students:

- $\quad$ inadequate self-perception by gifted students, low level of self-acceptance;

- $\quad$ presence of difficulties in relationships with peers (inability to establish interaction; problems in solving conflict situations; low sociometric status in the group); - difficulties of self-realization in the company of peers (gifted are already initially in tension, feel discomfort next to classmates, but there is a desire to be accepted, respected);

- $\quad$ low level of behavioral flexibility, etc. (3).

All the results show the need for a special approach to such an unconventional category as "gifted children. But sometimes our priorities in our work do not coincide with what is valuable for children and what parents and teachers think about children's values. 


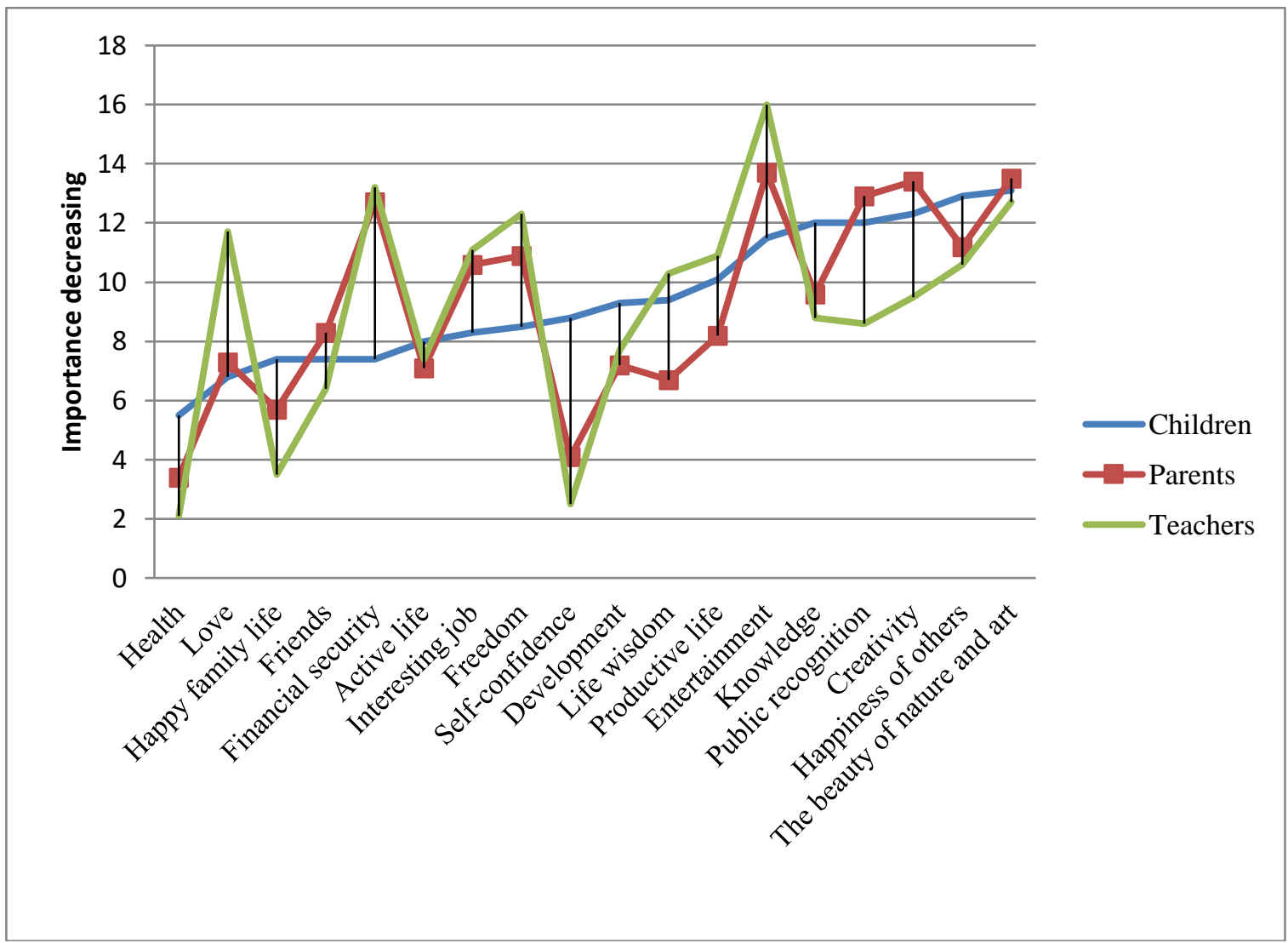

Fig 1

Perception of children's terminal values by teachers and parents

The data obtained are arranged in such a way that the most significant values are closer in the $\mathrm{X}$-axis. The more distant the value is from the $\mathrm{X}$-axis, the less significant the value is for this group of respondents (3).

The data indicate a certain difference in the priority terminal values of children and adults' perception of this. This is important and shall be taken into account when determining the content of work with gifted students.

Based on the available data, we believe that the work on overcoming difficulties of social development of gifted children can include the following directions:

- $\quad$ creating a field of self-realization based on the child's subjectivity in the system of social relations, the main characteristics of which are the organization of joint activities of children and adults, expanding the sphere of communication, and forming the child's reflective position;

- $\quad$ formation of leadership qualities based on personal self-sufficiency;

- $\quad$ formation of flexible behavior in solving situations of social choice;

- $\quad$ formation of adequate self-esteem through the development of the ability to self-evaluate and adequately evaluate external events;

- $\quad$ stimulation of self-development through the development of volitional and communicative qualities (2).

In recent decades, Kazakhstan has accumulated serious and interesting experience in working with gifted children. The Decree of President of the RK No.3002 dated May 24, 1996 "On state support and development of schools for gifted children" promoted the intensification of work with talented children and youth in the republic.

The new research and educational center - "Daryn" Republican Research and Practical Center of the Ministry of Education and Science of Kazakhstan - was founded by the 
Resolution No.256 of the Government of Kazakhstan dated March 24, 1998 for its implementation.

For 23 years of experience, "Daryn" scientific-practical center with the support of the Ministry of Education and Science has organized and conducted a number of significant world subject academic competitions (2003. - The International Academic Competition in the Russian language for graduates of the CIS and Baltic countries, 2006. - The 7th Asian Academic Competition in Physics, 2010. - 51st International Mathematical Academic Competition, 2012. - 46th International Mendeleev Chemistry Academic Competition, 2014. - 45th International Academic Competition in Physics, 2015 International Academic Competition in Computer Science, 2017 51st International Mendeleev Academic Competition in Chemistry)

Currently, there are more than 130 specialized educational organizations for gifted children. "Daryn" Republican Center is represented by a number of laboratories, among them - the "Laboratory of Giftedness of Elementary and Middle-aged Schoolchildren", the purpose of the laboratory is to create conditions for development of students' interest in various types of sciences, the formation of knowledge, skills and abilities in research, creative activities of junior students and teenagers, development of spiritual and creative personality, formation of all Kazakhstani identity and unity, implementation of scientific-methodological support of psychological support of gifted children and youth. The main activities of the laboratory are to create conditions for the identification, selection and support of giftedness; to organize and conduct events for gifted children of the republic (academic competitions, contests, tournaments, exhibitions, meetings, conferences, etc.) in different areas and subjects of natural-mathematical and sociohumanitarian cycles, in the fields of culture, art, sports, military affairs; public relations and coordination of work with parents of primary and secondary school age (persons replacing them); organization and conduct of psychological trainings for development of intellectual and personal spheres of gifted children and youth; organization and conduction of events for teachers-psychologists to improve their professional skills, prestige of psychologists in education.

Laboratory "Intellect and International Cooperation", provides the implementation of the state program for the search, selection, training and development of gifted children in the republic.

Among the priority tasks of the laboratory were the development of a system of methods for identifying gifted children; development of technologies for identifying and selecting talented children and youth in the Academic competition, intellectual competitions, contests, intellectual games; cooperation with educational organizations of the republic, CIS countries and foreign countries on giftedness.

Laboratory coordinates and provides organization of the Academic competition, competitions in various areas (stages of the Academic competition, development of tasks, criteria for their checks, methodological recommendations); regulatory and legal documentation of intellectual competitions and Academic competition; provides training of the team of the Republic of Kazakhstan on the subjects of natural and mathematical cycle in the Academic competition shift profile school, in training camps, etc.;

Laboratory of Pedagogical Skills was established in order to provide continuous professional development of a teacher in terms of updating the content of the Kazakhstani education, ensuring the development of specialized educational organizations of the republic;

The main objectives of the laboratory is to improve the professional competence of teachers in terms of updating the content of education; scientific and methodological 
support and coordination of research and innovation, creating conditions for teachers to choose the content, forms and methods of work, contributing to the development of his professionalism and creativity; compilation and distribution of best teaching experience of teachers-innovators; cooperation with leading Kazakhstani and foreign educational organizations in order to exchange experiences and implement best practices;

Laboratory specialists implement educational programs for training and improving the competence of teachers to work with children; conducts monitoring studies develop scientific and methodological literature; provide international and national conferences forums, festivals, project meetings, discussion platforms on training and education to update the content of education and summarizing the innovative experience and professional skills of teachers.

Characterizing Kazakhstan's experience in working with gifted children, it is important to name the "Baldauren" Republican Educational and Recreational Center, which has been carrying out educational and recreational activities year-round for more than 16 years. On a 20-day shift 288 participants and winners of international, republican and regional academic competitions and contests in history and geography, Kazakh, Russian, English languages, winners of projects under the "Rukhani Jangyru" program, laureates and diploma holders of creative competitions come.

The Baldauren Republican Center consists of several complexes: educational, upringing, sports and recreational and others.

36 teachers in the educational complex provide educational activities with children, including with the highest category - 27\%; the first category has $32 \%$ of teachers, the second category has $29 \%$ of the pedagogical staff.

Within the framework of educational activities, teachers are united in methodological associations: teachers of mathematics, physics, computer science; teachers of natural sciences; teachers of Kazakh language and literature; teachers of Russian and foreign languages; teachers of physical culture. The educational complex is actively working on the implementation of the scientific and pedagogical project "National Children's Academy of Young Researchers of Kazakhstan", aimed at supporting talented and gifted children of secondary schools, development of distance learning system and supporting young researchers in mastering academic subjects in connection with the transition to the 12-year system of education. Teachers of the Center have developed their own programs and teaching aids: "Qazaq otbasy" atty 9-synyp okushylaryna arnalgan agylshyn, kazak tilderi boiynsha (B.A.Beketay, S.S.Kaliyeva), "On sausaktan oner tamgan, kazagym" atty orys mektepterindegi 7-synyp okushylaryna kazak tili panine arnalgan" (G.Z.Daulenova, A.B.Bytisheva); "Basics of Speech Culture" for students in grades 8-9 (G.T. Daulbaeva), "Oratory and Rhetoric" for students in grades 5-6 (G.A. Baibasunova); "Using Information Technology in History Classes" (A.A. Yakovenko)

The main objective of the educational complex is to create positive conditions for quality education aimed at the formation, development and professional formation of a competitive personality on the basis of national and universal human values, science and practice. Not less than 288 students representing all Republic of Kazakhstan study during each shift. The participants of the shift are distributed on 14 educational classescompletes.

As part of the educational complex the development and implementation of thematic shifts for children and teenagers is provided, there is a department of methodological support and control. Employees of the department develop programs and content of the camp shifts. The main mission of the educational complex is to create a creative atmosphere, moral and psychological climate, goodwill, everything that contributes to 
the development of each student's personality, the formation of his active life position, the formation of a children's temporary association in general. The theme of the shifts changes annually, but the essence remains the same: building knowledge of history, traditions, customs, language and culture, thereby fostering a sense of identity, familiarizing ourselves with the treasures of national culture, and building national identity.

In 2004-2005 the teachers of the Center tested and introduced the author's programs: DAR - Detskaya Akademiya Rosta (Children's Academy of Growth) (D.V.Lepeshev) and DIVO - Detskiy Institut Velikih Otkrytiy (Children's Institute of Great Discoveries) (Ye.N.Vigovskaya, D.V.Lepeshev), promoting forming and development of creative potential not only for children, but also for the adult community of teachers.

A number of creative associations on interests - beadwork, embroidery, frivolita, watercolor, radio technique, macramé, lace weaving and sewing - function in the department of additional education, as well as, there is a "Zhastar" teaching team.

Implementation of the physical education program of the Republic of Kazakhstan with the use of effective educational and health programs for the center is provided in the framework of the physical education and tourism complex. The priority objectives of the complex functioning are: health promotion, creating conditions for physical education, sports and tourism and others.

The complex in accordance with the main goal and objectives carries out recreational work in the following areas: physical education, sports and tourism.

The presented work experience shows the serious attention in the Republic of Kazakhstan to the work with gifted children.

As part of the study of the problem we conducted a study on the giftedness of students of the "Zerde" gifted children's school in Nur-Sultan $(n=100)$.

According to the results of the diagnostic method "Map of Giftedness" carried out by D. Haan and M. Kaffa, we made a graph which illustrates the relationship between the degree of parental giftedness (Figure 1).

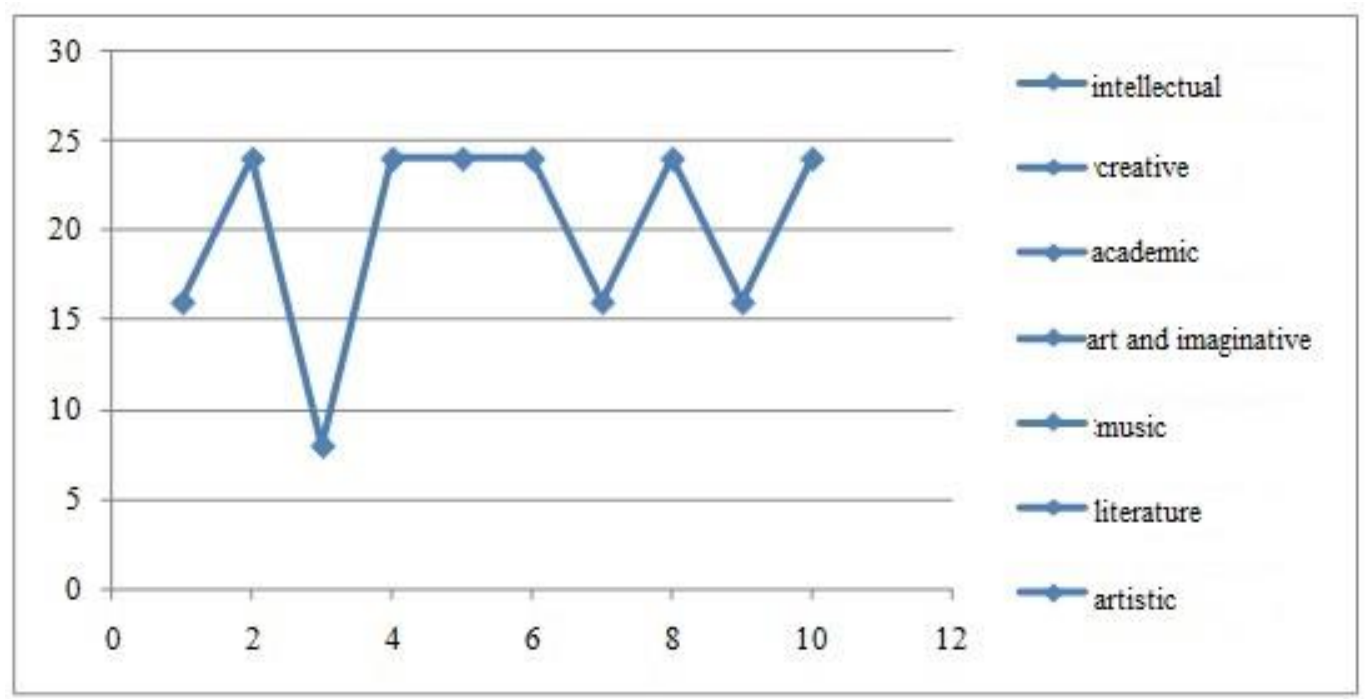

Fig 2

Results of the technique «Map of giftedness» $(n=100)$

According to Figure 1, in the minds of parents, students also show creative, artistic, music, literary, technical, and athletic abilities, each accounting for $12 \%$ of the total; intellectual, artistic, managerial skills account for $8 \%$; and $4 \%$ have academic potential. 
According to the questionnaire "How to recognize giftedness" L.G. Kuznetsova, L.P. Cricket, shown in Figure 2, the most clearly demonstrated sports talent - 52\%, musical talent $-48 \%$, unusually $-40 \%$, technical ability, scientific ability is determined by $36 \%$, literary talent, artistic ability and artistic talent is $32 \%$.

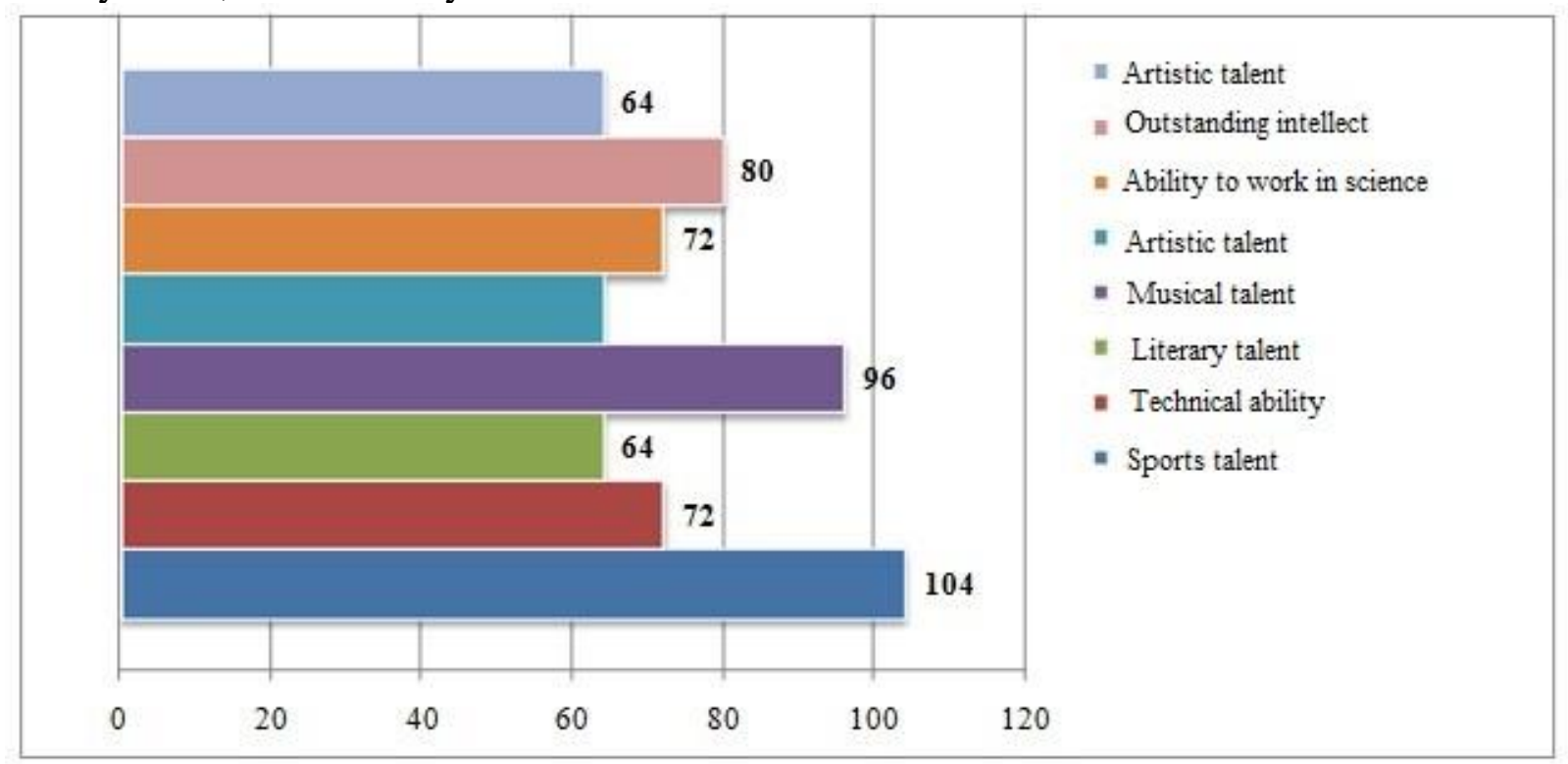

Fig 3

Results of the questionnaire «How to recognize giftedness» $(n=100)$

According to Figure 3, the level of the nine characteristics usually observed in gifted children, according to the method of "Assessment of General Giftedness" by A.I. Savenkov is laid out as follows:

- $\quad$ curiosity, vocabulary $84 \%$

- $\quad$ ability to construct and think logically $72 \%$

- $\quad$ heightened sensitivity to problems $64 \%$

- $\quad$ ability to assess $60 \%$

- $\quad$ inventiveness, persistence $52 \%$

- $\quad$ predictability $48 \%$

- $\quad$ performance conformity $44 \%$. 


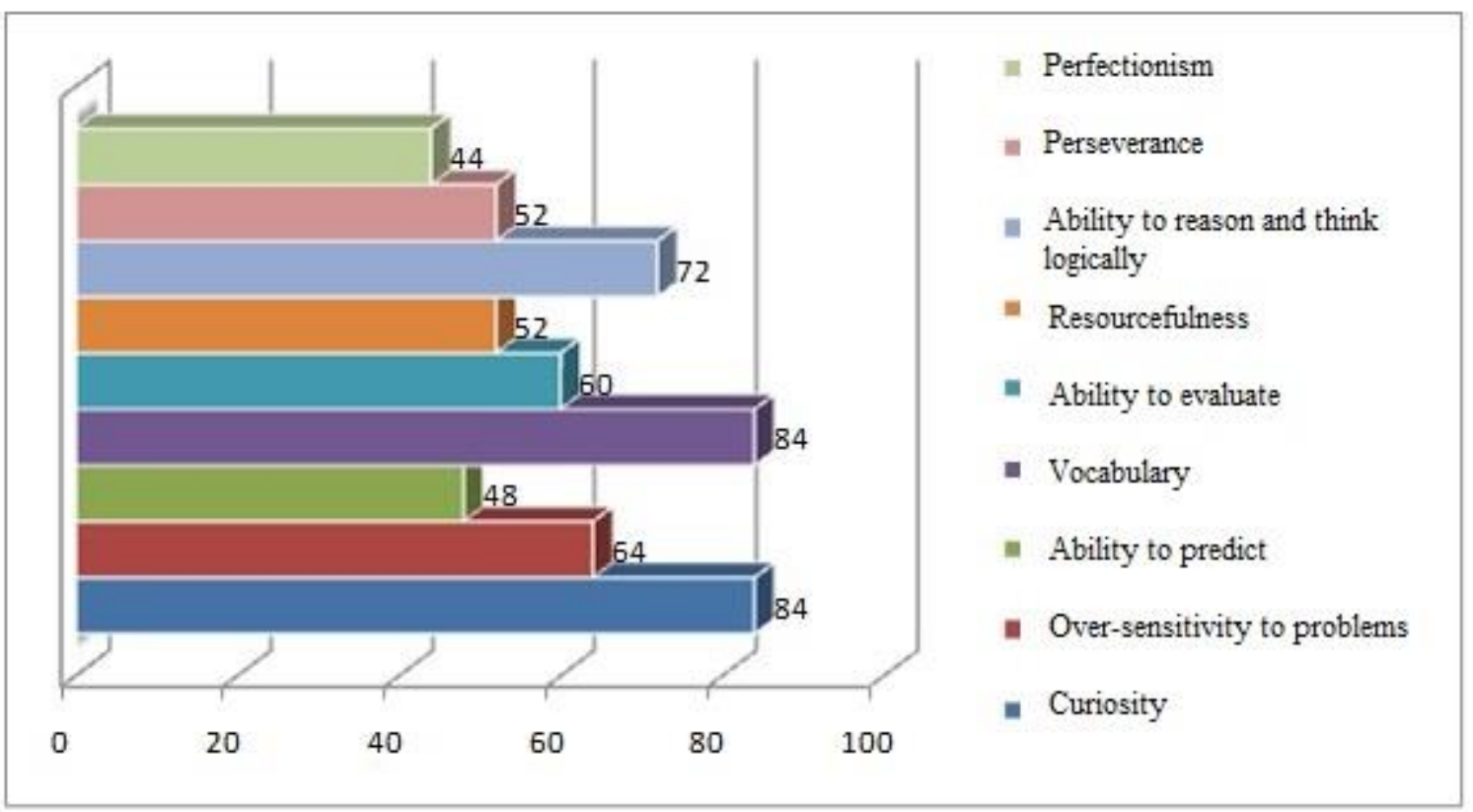

Fig 4

Results of the methodology «Assessment of General giftedness» $(n=100)$

Consequently, studies in Kazakhstan have concluded that the development of gifted children will be achieved through a series of actions in four areas:

1. Updating the content of the curriculum.

2. Use of differentiated and individualized forms of learning, including the development of individual educational pathways.

3. Use of advanced ICT technologies for remote learning.

4. Integration of basic education and additional education.

Conditions for successful work with gifted children:

- $\quad$ understanding of the importance of this work by each team member, and in this context there is an increasing emphasis on creating a positive motivation to learn;

- $\quad$ creation and continuous improvement of the methodological system for gifted children;

- $\quad$ recognition by teachers and school authorities that creating a system of work with gifted children is one of the school's priorities;

- $\quad$ professional and personal qualification of gifted teachers.

The results obtained in the Russian Federation and Kazakhstan suggest the need to increase attention to socio-pedagogical work with gifted children.

In this regard, we conducted a survey of teachers and specialists of educational organizations in the Russian Federation $(n=225)$ and in Kazakhstan $(n=200)$.

According to the results of the survey, $16 \%$ of teachers-respondents in Kazakhstan work with gifted children, in Russia - $80 \%$ of teachers face in their work, in their opinion, with gifted children.

In terms of qualities that distinguish gifted children, it is necessary to note the solidarity of opinions of teachers from Russia and Kazakhstan (Fig. 4). In their opinion, gifted children, first of all, are characterized by a wide erudition and high academic performance, the rapidity of performance of academic tasks. At the same time, Russian teachers consider gifted children to be more conflicted $(15 \%)$ than teachers from Kazakhstan (3\%) 


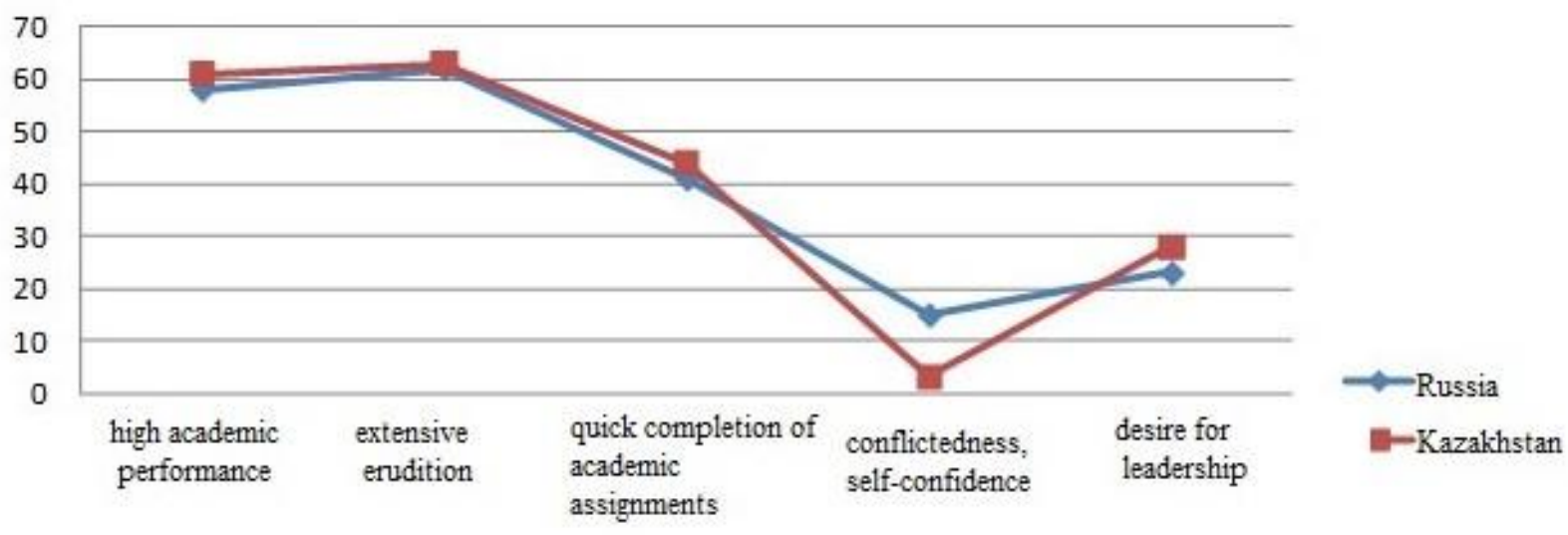

Fig 5

The quality that distinguishes gifted children (data matching)

Teachers in Russia name the promotion of talent (82\%), assistance in self-determination $(59 \%)$, and regular diagnostics $(54 \%)$ as priority areas of work with gifted children.

Teachers in Kazakhstan are fairly even in assessing the importance of all areas of work with gifted students $(\sim 50-60 \%)$, without paying special attention to helping gifted students to establish positive relationships $(20 \%)$.

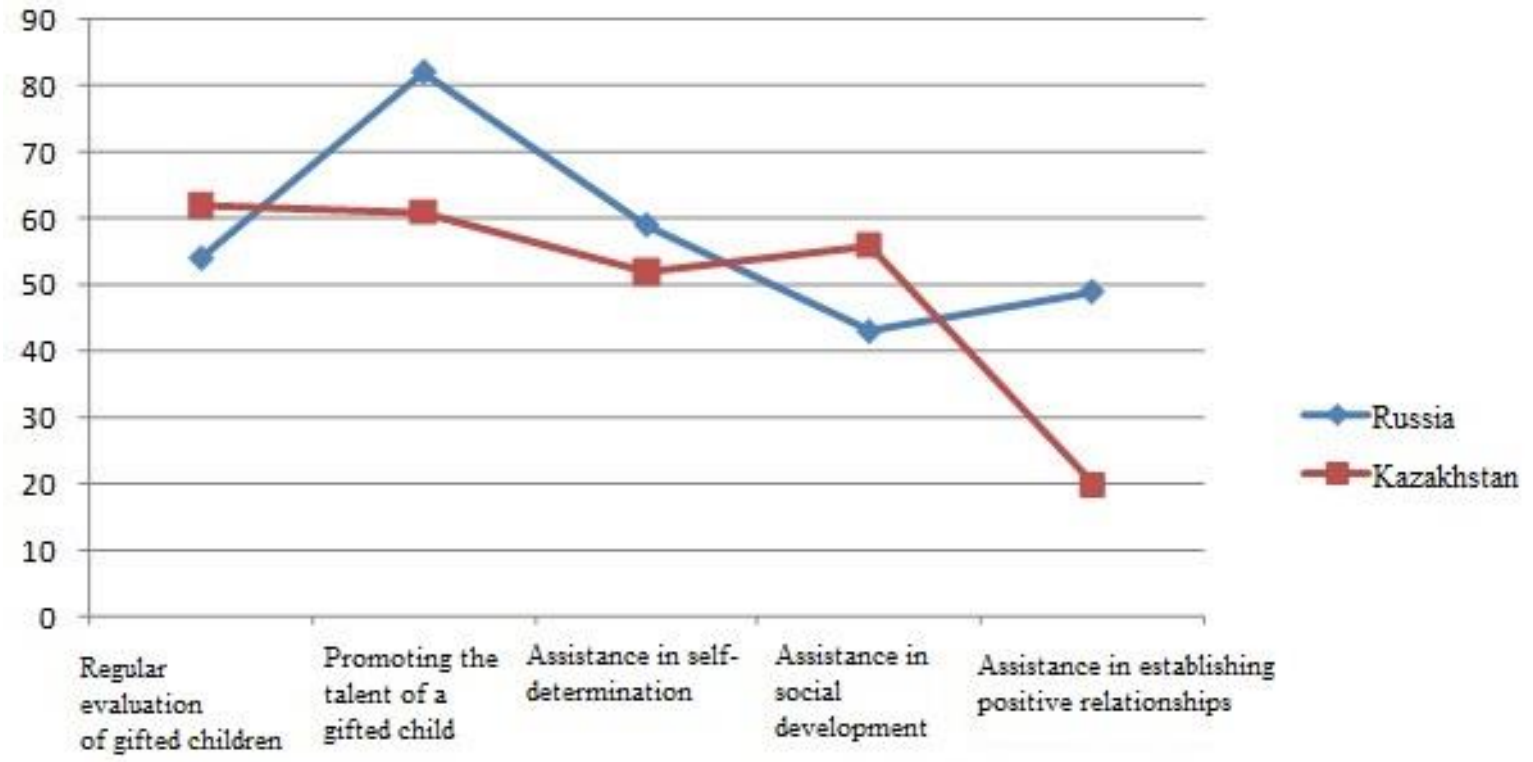

Fig 6

Priority areas of work with gifted children (data comparison)

Most teachers surveyed in Russia have experience working with gifted children, while only half of the teachers surveyed in Kazakhstan believe they have experience working with gifted children (47\%). Many teachers lead clubs and sections, organize individual work with gifted children, promoting their self-determination and creating conditions for the development of abilities. Many teachers prepare their students to participate in competitions and contests of different levels, a number of them are organizers of competitions and contests.

Teachers of the Russian Federation work with gifted children mainly through such forms of work as: clubs, sections, electives, intellectual games, competitions, academic competitions, contests, exhibitions, shows, preparing MMP presentations, training in foreign programs, consulting with the help of the Internet.

Teachers in Kazakhstan call such forms of work with gifted children as traditional: 
research activities, intellectual marathons and competitions, hobby groups, elective courses, scientific and practical conferences, seminars, elective courses, etc.

Among the innovative forms teachers in Russia and Kazakhstan name: robotics, trainings, coaching, trainings, design, work in STEM format, express school, etc.

The effectiveness of socio-pedagogical work with gifted children, according to teachers in Russia and Kazakhstan, is evidenced by different results. Russian teachers at the same time appreciate the educational results of children, their participation and victories in competitions and academic competitions, paying considerable attention and importance to the ability of children to communicate, work in pairs to solve conflicts. Less important to them was the availability of friends for gifted children.

The surveyed teachers of RK pay the most attention to the participation and victories of gifted schoolchildren in competitions and academic competitions. The importance of educational results is quite significant, while the social side of the development of gifted children is given much less attention according to the results of the survey. Such results as the ability of gifted children to communicate, to work in pairs, to solve conflict situations, to have friends are of little importance (Fig. 7).

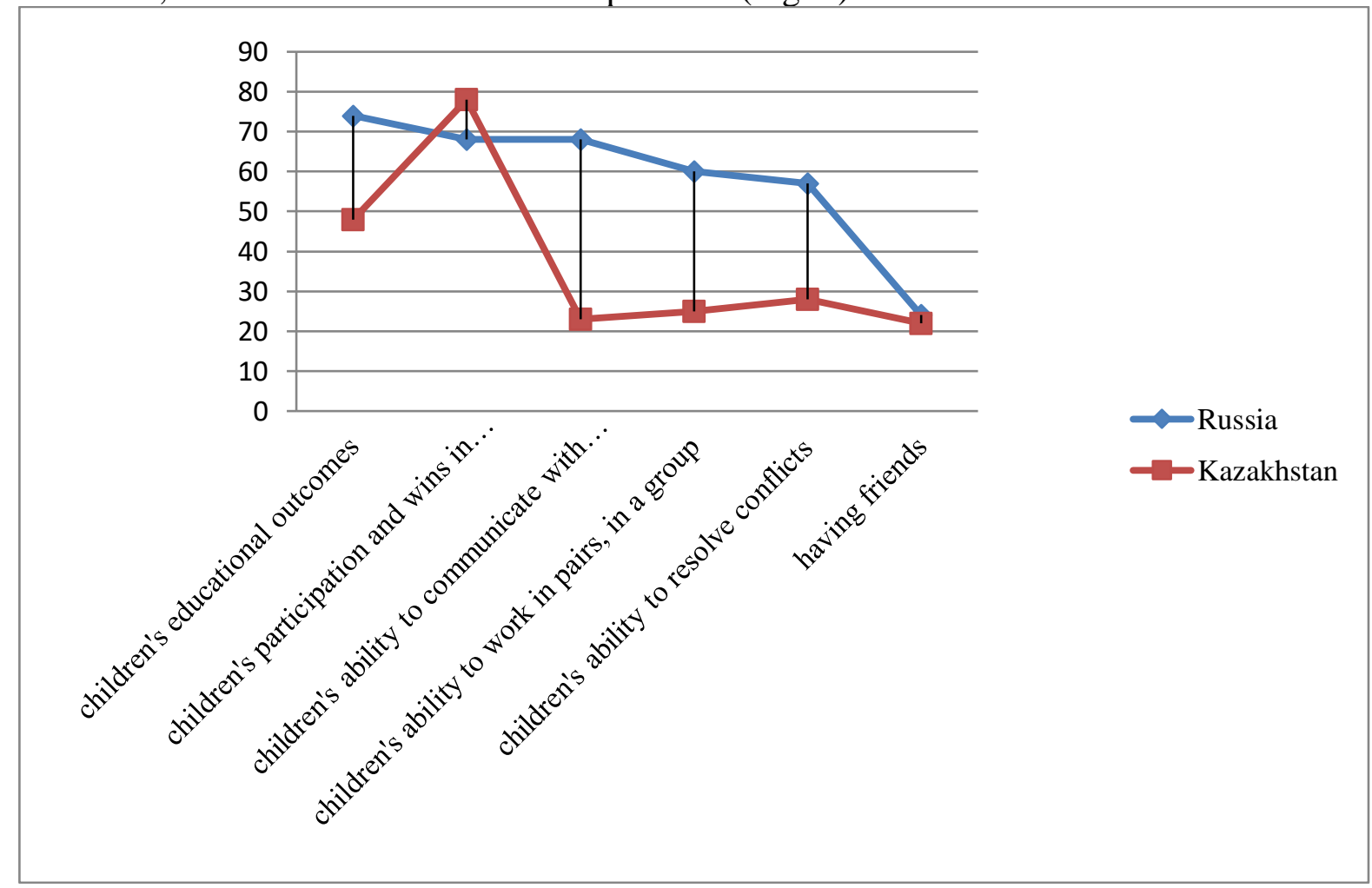

Figure 7

Results of socio-pedagogical work with gifted children (data comparison)

\section{Conclusion}

The conducted study allowed us to perform a comparative analysis of the experience of socio-pedagogical work with gifted schoolchildren in the Russian Federation and Kazakhstan. On the basis of the analysis of the received results we can name the following features of experience of two countries in this direction of work:

1. Russia and Kazakhstan are actively developing work with gifted children and currently have serious and interesting experience in this area.

2. The work with gifted children in Russia and Kazakhstan is carried out both at school and in the organizations of additional education. 
3. There are special centers for work with gifted schoolchildren in Russia and Kazakhstan, which are active in the development of this category of children and are centers that accumulate modern developments in the field of work with gifted children. At the same time in Russia "Sirius" Educational Center invites children to thematic shifts in the city of Sochi, and the center "Daryn" in Kazakhstan is stationary in different regions of the country and is represented by a network of educational organizations and laboratories. Currently, in Russia there is an active discussion of the opening of regional representative offices of "Sirius" Educational Center in the regions of the Russian Federation.

4. Gifted children in Russia can come to bright thematic shifts of "Artek" International Children's Center and "Orlyonok" All-Russian Children's Center. In Kazakhstan gifted children become participants of shifts of "Baldauren" Republican educational and health center. These centers have a rich history and bright, rich programs that allow children with different types of giftedness to rest and develop.

5. Social and pedagogical tasks in work with gifted children are solved in educational organizations of Russia and Kazakhstan, but in different degree, with different content and different priorities.

6. Schools in both Russia and Kazakhstan are focused mainly on the development of abilities and success of gifted students.

7. The results show that the work on the social development of a gifted schoolchild is quite significant in the organizations of additional education in Russia, while in the results of teachers in Kazakhstan, these items do not occupy high positions.

The results obtained indicate the presence of serious, interesting experience of sociopedagogical work with gifted students both in the Russian Federation and in Kazakhstan. At the same time each country has its own specifics in the work, which could be taken into account to improve the efficiency and quality of work with gifted students.

Based on the comparative analysis of the experience of socio-pedagogical work with gifted schoolchildren of the Russian Federation and Kazakhstan, the following recommendations can be developed:

1. Increased attention to socio-pedagogical work with gifted children and creation of conditions for their social development in schools and organizations of additional education.

2. Implementation of regular socio-pedagogical and psycho-pedagogical diagnostics of gifted children (identification of gifted children; determining the type of giftedness; establishing a bank of gifted children; regular diagnostics to determine the needs of gifted children, the features and difficulties of their social development).

3. Development of programs of socio-pedagogical work with gifted students, which will create conditions for the timely solution of age tasks of development and socialization of gifted students, their self-realization, development of subjectivity in different types of activities and in different social roles.

4. Organization of work to improve the psychological and pedagogical competence of teachers in issues of socio-pedagogical work with gifted children.

Consideration and implementation of these recommendations will, in our opinion, improve the effectiveness of socio-pedagogical work with gifted students in different types of educational organizations of the Russian Federation and Kazakhstan.

\section{References}

Bogoyavlenskaya, D.B. (2004). Working concept of giftedness. Educational issues, 2, 46-68.

URL: 
https://elibrary.ru/item.asp?id=9172194

Zakharova, A. I. N. Grushetskaya, O. S. (2019). Shcherbinina Features of sociopedagogical work with gifted schoolchildren in the conditions of modern educational organizations // Science for Education Today (previous name Vestnik of Novosibirsk State Pedagogical University). 9(1), 27-42. DOI: http://dx.doi.org/10.15293/2658

Grushetskaya, N., Shcherbinina, O.S. (2018). Interaction of gifted students with microsociety as a condition for their social development. Prospects of Science and Education, 5(35), 136-144. DOI: http://dx.doi.org/10.32744/pse.2018.5.15

Leytes, N.S. (2003). On signs of childhood giftedness.Issues of Psychology, 4, 13-19. URL: https://elibrary.ru/item.asp?id=9203403

Lepeshev, D.V. A.A. (2018). Karaulova Methods of diagnostics of gifted children. Newsletter of the Omsk Regional Institute, 3, 138-142. URL: https://elibrary.ru/item.asp?id=32765115

Leutina, L.A. (2014). Socialization of Children in Modern Pedagogical Research. Educational Issues, 3, 152-173. DOI: http://dx.doi.org/10.17323/1814-95452014-3-152-173

Meshkova, N.V. (2015). Foreign Studies of Giftedness: The Socio-Psychological Aspect. Contemporary Foreign Psychology. 4(1), 26-44. (Electronic resource) URL: https://elibrary.ru/item.asp?id=23733139

Panov, V.I. (2014). Giftedness: From Paradoxes to Subjectivity Development. MAMI NEWSLETTER OF THE MOSCOW STATE TECHNOLOGICAL UNIVERSITY,4(5), 129-137. URL: https://elibrary.ru/item.asp?id=23028561

Popova, L.V. (2009). Educational programs for gifted children in European countries.Psychological Science and Education. 4, 101-114. URL: https://elibrary.ru/item.asp?id=12991708

Smirnov, V.A. Khazova. S.A. (2017). Experience in implementing a program of personal resource development for gifted high school students as part of psychological and pedagogical support of the socialization process. Newsletter of Kostroma State University. Series: Pedagogy. Psychology. Sociokinetics, 23(5), 39-43. URL: https://elibrary.ru/item.asp?id=32728541

Khazova, S.A. (2013). Gifted teenager as a subject of interpersonal interaction. Newsletter of N.A. Nekrasov Kostroma State University. Series: Pedagogy. Psychology. Social work. Juvenile science. Sociokinetics, 19(2), 102-107. URL: https://elibrary.ru/item.asp?id=19960099

Yurkevich, V.S. (2018). Intellectual giftedness and social development: a contradictory relationship. Contemporary Foreign Psychology. 7(2), 28-38. DOI: $10.17759 /$ jmfp.2018070203

Davis, J.L., Robinson, S.A. (2018). Being 3e, a new look at culturally diverse gifted learners with exceptional conditions: An examination of the issues and solutions for educators and families. Twice Exceptional: Supporting and Educating Bright 
and Creative Students with Learning Difficulties. 18, 278-289. DOI: http://dx.doi.org/10.1093/oso/9780190645472.003.0017

Guez, A., Peyre, H., Le Cam, M., Gauvrit, N., Ramus, F. (2018). Are high-IQ students more at risk of school failure?. Intelligence. 71. Pages 32-40. DOI: http://dx.doi.org/10.1016/j.intell.2018.09.003

The study was supported by the Russian Foundation for Basic Research; project No.18-01300867 